\title{
Stocking rate and grazing frequency effects on Nebraska Sandhills meadows
}

\author{
JERRY D. VOLESKY, WALTER H. SCHACHT, AND DEVYN M. RICHARDSON
}

Authors are Associate Professor, Agron. and Hort. Dept., University of Nebraska-Lincoln, West Central Research and Extension Center. 461 West University Drive, North Platte, Nebr. 69101 (jvoleskyl@unl.edu); Associate Professor, Agron. and Hort. Dept., University of Nebraska-Lincoln, P.O. Box 830915, Lincoln, Nebr. 68583; and Environmental Scientist, HDR Inc., I7III Preston Rd., Suite 200, Dallas, Tex. 75248. Research was a portion of the third author's M.S. degree work, Agron. and Hort. Dep., University of Nebraska-Lincoln.

\section{Abstract}

Nearly one-half million ha of the Nebraska Sandhills is comprised of highly productive wet meadows. A study was conducted from 1998 to 2001 to evaluate the effects of stocking rate and grazing frequency on herbage dynamics, disappearance, and composition of a wet meadow dominated by cool-season vegetation. Defoliation characteristics were measured on 2 key species. Stocking rates were 148,296 , and $444 \mathrm{AUD} \mathrm{ha}^{-1}$ combined with a grazing frequency of 3 (F3) or 5 (F5) times. Cumulative standing crop disappearance and height reduction increased linearly with increasing stocking rate. Disappearance was $1,920,2,700$, and $3,090 \mathrm{~kg} \mathrm{ha}^{-1}$ for the 148,296 , and $444 \mathrm{AUD} \mathrm{ha}^{-1}$ stocking rates, respectively. Greater disappearance at the highest stocking rate was expected based on calculated intake estimates for that stocking rate. Percentage of tillers grazed and percentage height reduction increased with stocking rate for both key species. Percentage of tillers grazed was greater under F3 compared to F5. This likely was caused by higher grazing pressures under the F3 treatment at each grazing period. Frequency of occurrence of the primary plant species or groups was not affected by stocking rate or grazing frequency during any year of the study ( $P>$ 0.05 ); however, frequency of occurrence of legumes and Kentucky bluegrass (Poa pratensis L.) was higher in grazed pastures compared to the control. The abundance of soil moisture in these meadows appeared to mitigate the effects of heavier defoliation associated with higher stocking rates. However, defoliation of the taller grasses and sedges resulted in a more open canopy allowing shorter-statured species to increase. Overall, stocking rate affected more response variables than grazing frequency and the productivity of our wet meadow site would potentially support a stocking rate of $296 \mathrm{AUD} \mathrm{ha}^{-1}$.

Key Words: subirrigated meadow, wet meadow, forage quality, herbage dynamics

Wet meadows comprise about $10 \%$ of the 4.8 million ha in the Nebraska Sandhills. These meadows are typically located in broad, flat valleys between elevated dune formations (Rundquist, 1983). Soil water is within rooting depth of the meadow vegetation during most of the growing season. Introduced cool-season

A contribution of the University of Nebraska Agricultural Research Division, Lincoln, Nebr. Journal Series No. 14277. This research was supported in part by funds provided through the Hatch Act.

Manuscript accepted 8 Feb. 04.

\section{Resumen}

Casi medio millón de hectáreas del la región "Nebraska Sandhills" son praderas húmedas altamente productivas. Se condujo un estudio de 1998 a 2001 para evaluar los efectos de la carga animal y la frecuencia de apacentamiento en las dinámicas del forraje, desaparición y composición de una pradera húmeda dominada vegetación de estación fría. Las características de defoliación se midieron en dos especies clave. Las cargas animal fueron: 148, 296 y 444 AUD ha $^{-1}$ combinadas con frecuencias de apacentamiento de 3 (F3) y 5 (F5) veces. La desaparición acumulativa de la biomasa en pie y la reducción de altura se incremento linealmente al aumentar la carga animal. La desaparición fue: $1,920,2,700$ y $3,090 \mathrm{~kg} \mathrm{ha}^{-1}$ para las cargas animal de 148, 296 y 444 AUD ha ${ }^{-1}$ respectivamente. Se esperaba una mayor desaparición con la carga animal mas alta, esto basado en el consumo calculado para esta carga animal. En ambas especies calve el porcentaje de hijuelos apacentados y el porcentaje de reducción de altura se incremento al aumentar la carga animal. El porcentaje de hijuelos apacentados fue mayor en F3 que F5. Esto probablemente fue causado por la mayor presión de apacentamiento bajo el tratamiento $\mathrm{F} 3$ en cada periodo de apacentamiento. En ninguno de los años del estudio $(P>0.05)$ la frecuencia de ocurrencia de las principales especies o grupos de plantas fue afectado por la carga animal o la frecuencia de apacentamiento; sin embargo la frecuencia de ocurrencia de leguminosas y "Kentucky bluegrass" (Poa pratensis L.) fue mayor en los potreros apacentados que en los control sin apacentar. La abundancia de humedad en el suelo de estas praderas parece mitigar los efectos de una mayor defoliación asociada con las cargas animal altas. Sin embargo, la defoliación de los zacates altos y los juncos resulto en una copa más abierta permitiendo a las especies cortas saturadas de aumentar. En general la carga animal afectó mas variables respuesta que la frecuencia de apacentamiento y la productividad de nuestro sitio de praderas húmedas pudiera potencialmente soportar una carga animal de 296 AUD ha ${ }^{-1}$.

grasses and legumes, along with native sedge and rush species, dominate many Sandhills meadows in contrast to upland sites that are dominated by native, warm-season grasses (Ehlers et al. 1952). Meadows were originally dominated by warm-season grasses, many of which are still found on the surrounding upland range (Poole 1914).

Wet meadows have been used primarily as the source of hay fed to cattle during the dormant season (Coady and Clark 1993). 
Hay harvest in the Sandhills generally takes place from late June to early August. Hay harvest in late June captures more vegetative plant growth resulting in higher hay quality. However, hay harvest at this time is not always an option because of inundated or wet soils. Hay harvested later in the growing season contains more reproductive plant growth that is lower in forage quality and may not have the nutrient content needed to meet the requirements of spring-calving cows (Adams et al. 1994).

Producers rarely use meadows for grazing during the growing season, but rather during fall or winter when soil conditions are drier or the soil is frozen (Coady and Clark 1993). Fall or winter grazing removes growth that occurs after midsummer haying. Grazing meadows in the spring maintains meadow plants in a vegetative stage of growth for a prolonged period, thereby delaying stand maturation resulting in higher quality hay harvested later in the growing season when soils are drier (Volesky et al. 2002). Adams et al. (1994) found that grazing meadows in the spring when forage quality is higher and the requirements for lactating cows are greater resulted in increased growth rates of calves and improved cow body condition. Horney et al. (1996) reported similar results when grazing meadows in the spring and early summer. When meadows dominated by cool-season species are grazed in spring before upland sites are ready, profitability increases because less hay is fed during that period (Adams et al. 1994).

Previous meadow studies have addressed several aspects of cow and calf production and forage production and quality (Adams et al. 1994, Horney et al. 1996). However, to our knowledge, no research has been conducted evaluating specific characteristics of grazing strategies, such as grazing frequency and stocking rate. The USDASCS Nebraska Technical Guide recommends stocking rates for wet meadow sites in the Sandhills from 118 to 148 AUD ha ${ }^{-1}$ (USDA-SCS 1981). Because of the high proportion and production potential of nonnative species in wet meadows, a stocking rate higher than recommended may be feasible. Optimum frequency or number of grazing periods per growing season, at a particular stocking rate, is unknown for wet meadow sites.

This study was conducted to assist in the development of grazing management recommendations for Sandhills wet meadows. The primary objective was to determine the effect of stocking rate and grazing frequency on herbage dynamics, standing crop disappearance, defoliation of key species, and species composition. We hypothesized that (1) standing crop disappearance and tiller use would increase at a constant rate as stocking rate or grazing pressure increased, and (2) stocking rate and grazing frequency would affect species composition.

\section{Material and Methods}

\section{Study Site}

The study was conducted from 1998 through 2001 at the University of Nebraska's Gudmundsen Sandhills Laboratory located $11 \mathrm{~km}$ northeast of Whitman, Nebr. $\left(42^{\circ} 04^{\prime} \mathrm{N} 101^{\circ} 26^{\prime} \mathrm{W}\right.$, elevation $=1,075 \mathrm{~m}$ ). The average maximum daily temperatures range from $2^{\circ} \mathrm{C}$ in January to $32^{\circ} \mathrm{C}$ in July. Mean annual precipitation at the site is $453 \mathrm{~mm}$, about $75 \%$ of which occurs during the growing season from April through September. Annual precipitation was $103,74,101$, and $127 \%$ of the long-term mean from 1998 through 2001, respectively (Fig. 1). The study site (1.1 ha) was located on a wet meadow with soils classified as Gannett-Loup fine sandy loam (coarseloamy mixed mesic Typic Haplaquoll). Cool-season grasses, sedges, and rushes dominated the meadow. The most common grasses were slender wheatgrass [Elymus trachycaulus (Link) Matte], redtop bent (Agrostis stolenifera L.), and timothy (Phleum pratense L.). Other grasses present included Kentucky bluegrass ( $\mathrm{Poa}$ pratensis L.) and smooth bromegrass (Bromus inermus Leyss.). Woolly sedge (Carex lanuginosa Michx.) and several spike rush species (Eleocharis spp.) were also abundant. The primary legumes included white clover (Trifolium repens L.), alsike clover (Trifolium hybridum L.) and red clover (Trifolium pratense L.). Warm-season grasses present in minor amounts were prairie cordgrass (Spartina pectinata L.) and big bluestem (Andropogon gerardii Vitman). The study site had been hayed in the summer and grazed in the winter for the past several decades.

\section{Grazing Treatments}

There were 6 treatment combinations of 2 grazing frequencies and 3 stocking rates along with an ungrazed control. The 2 frequencies were repeated grazing periods in May, June, and August (F3); or May, June, July, August, and September (F5). The 3 stocking rates were 148,296, and 444 AUD ha ${ }^{-1}$. There were 3 replications (blocks), each comprised of 7 pastures.

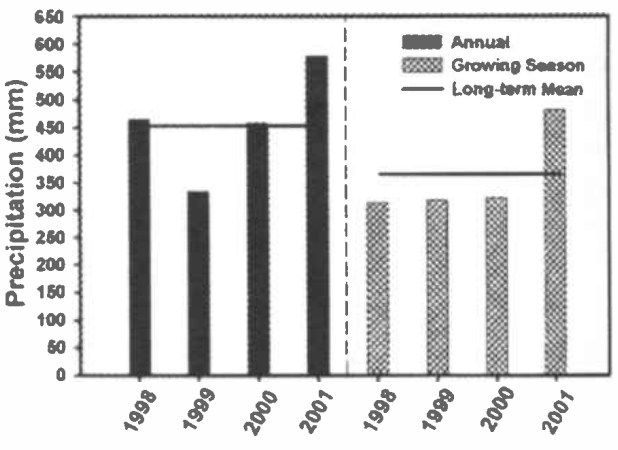

Fig. 1. Annual and growing season (Apr.Sep.) precipitation at the Gudmundsen Sandhills Laboratory near Whitman, Nebr.

Blocking was based on slope position within the meadow basin. Degree of soil wetness, duration of flooding, and proximity to water increased down slope. The 6 grazing treatments and ungrazed control were randomly assigned to the pastures within a block. Pastures were grazed with 2 yearling heifers ( $318 \mathrm{~kg}$ average weight) for 2 days per grazing period. Pasture size ( 0.02 to $0.09 \mathrm{ha}$ ) was varied to produce the planned stocking rates for each grazing frequency. Control pastures were 0.04 ha.

Grazing dates and recovery (non-use) periods were similar for all years. Grazing dates for grazing frequency 3 (F3) were mid-May, late-June, and mid-August with a 39-day recovery period between the first 2 dates and 50 days between the second and third dates. For grazing frequency 5 (F5), grazing dates were mid-month for May through September with an average 30 day recovery period.

\section{Vegetation Measurements}

Herbage standing crop and height were determined immediately prior to, and following each 2-day grazing period. The difference between pre- and post-grazing herbage standing crop represented disappearance. Control pastures were sampled at the same time as pre-grazing measurements occurred. Herbage standing crop and height were determined using a circular plexiglas disc-meter $\left(0.25 \mathrm{~m}^{2}\right)$ and following the procedures of Sharrow (1984) and Karl and Nicholson (1987). Fortyeight disc-meter measurements were taken at random locations in each pasture at each sampling event. For height, the disc was lowered and height recorded when approximately $10 \%$ of the leaf tips or inflorescences were in contact with the bottom of the disc. For herbage standing crop, the disc was dropped from $1 \mathrm{~m}$ and resting height of the disc recorded. For calibration, herbage within the $0.25-\mathrm{m}^{2}$ circular area was hand-clipped at every eighth 
disc-meter location. Herbage was clipped to ground level, bagged, and oven-dried at $60^{\circ} \mathrm{C}$ to a constant weight. Regression analysis (SAS 1995) was used to develop predictive equations relating disc resting height to standing crop. Tests for the effect of sampling date indicated a significant difference for data collected during May, June, and July compared to that collected in August and September. As a result, separate prediction equations were developed for the May, June, and July sampling periods $\left(R^{2}=0.82\right)$ and August and September sampling periods $\left(R^{2}=0.74\right)$.

For each pre- and post-grazing sampling date, clipped herbage samples from the 6 quadrats $\left(0.25 \mathrm{~m}^{2}\right)$ per pasture used to determine regression equations were combined and ground to pass through a $1-\mathrm{mm}$ screen. Nitrogen $(\mathrm{N})$ content was determined using a LECO CRN-1000 Elemental Analyzer'. Crude protein (CP) content was then expressed as $\mathrm{N} \times 6.25$.

Individual tillers of key forage species, slender wheatgrass and woolly sedge, were marked for repeated measurement of height and disappearance before and after each grazing period. These tillers were selected along $15-\mathrm{m}$ permanent transects in each pasture. Pastures for the 148, 296, and 444 AUD ha ${ }^{-1}$ stocking rate levels contained 3,2, and 1 transect, respectively. Control pastures had 2 transects. Prior to the initial grazing period each year, 25 tillers each of slender wheatgrass and woolly sedge were selected at random along the transects at approximately $0.3-\mathrm{m}$ intervals. For subsequent relocation, each tiller was marked with a colored, wire marker and a golf tee at the tiller base. Tiller height, as measured from the soil surface to the tip of the highest fully extended leaf blade, was recorded. Following the grazing period, the marked tillers were relocated and examined for evidence of grazing. For tillers that were grazed, remaining height was recorded. Tiller height reduction was calculated as the difference between pre- and post grazing height. Height of marked tillers within control pastures was determined at the same time as pre-grazing measurements occurred.

Measurements of herbage disappearance, quality, and height as well as disappearance of slender wheatgrass and woolly sedge were made only during 1998 and 1999. Herbage standing crop at the start of grazing in May was determined each of the 4 years of the study.

${ }^{1}$ LECO Corporation, 3000 Lakeview Ave., St. Joseph,.Mich. 49085-2396
Herbage standing crop was measured in all pastures at the end of the growing season(mid-October) in 1998 and 1999. Procedures for this sampling were identical to those used to sample pre- and postgrazing standing crop during the growing season. In January of each year, residual plant material was cut with a sickle-bar mower and removed from all pastures.

For grazed treatments, total production was calculated as the sum of the initial pre-grazing standing crop, difference in standing crop between pre-grazing of each subsequent grazing period and post-grazing of each previous grazing period, and end-of-season standing crop. Standing crop was harvested in one-half of each control pasture in mid-July (July-hay treatment) to simulate hay harvest. Three strips, 0.9 by $2.4 \mathrm{~m}$, were cut using a sickle-bar mower. The hay was raked and weighed, and a grab sample taken from each strip. Grab samples were weighed fresh (wet) and again after drying for 48 hours in a $60^{\circ} \mathrm{C}$ oven to determine dry matter content. The remaining half of the control pastures was not cut and herbage standing crop was sampled at the dates corresponding to the treatment pasture grazing periods. This half of the control pastures also contained the permanent transects that were used for individual tiller height measurements. For the Julyhay treatment, total production was calculated as the sum of the July hay yield and end-of-season standing crop.

Frequency of occurrence of plant species or groups was determined in August of each year along the same permanent transects used for height and disappearance measurements. The species and plant functional groups measured were slender wheatgrass, woolly sedge, Kentucky bluegrass, other cool-season grasses, warm-season grasses, other sedges, rushes, legumes, and forbs. The high plant diversity and density made it very difficult and time consuming to measure frequency of occurrence for other than the key forage species and plant functional groups. Fifty quadrats $(0.15$ by 0.15 m) were evaluated for frequency of occurrence at $0.3 \mathrm{~m}$ intervals along each transect line.

The experimental design was a randomized complete block with 3 replications. Each treatment combination of grazing frequency and stocking rate was represented in each replication. Standing crop disappearance, crude protein content, end-ofseason standing crop, and tiller defoliation were analyzed by analysis of variance using the General Linear Model Procedure
(SAS 1995). Experimental units were individual pastures. Grazing frequency and stocking rate were factor combinations of treatment and years were repeated factors. Contrasts were written to test for differences between the control and other treatments, July hay control and other treatments, the 2 levels of grazing frequency, and to test for linear and quadratic effects of stocking rate and the interactions with grazing frequency. Treatment effects were considered significant at $\mathrm{P}<0.05$ for all data. Grazing pressure (AUD $\mathrm{Mg}^{-1}$ ) was calculated for each grazing period using pregrazing herbage standing crop. Animal weights were divided by $454 \mathrm{~kg}$ to estimate animal unit (AU) equivalents. Regression analysis was used to fit equations to pasture means for the relationship between grazing pressure and percentage of tillers grazed and percentage height reduction for slender wheatgrass and woolly sedge. A non-linear procedure (NLIN; SAS 1995) was also used to fit a segmented quadratic and plateau model for both defoliation characteristics. Regression analysis also was used to fit equations to pasture means for the relationship between grazing pressure and percentage standing crop disappearance.

\section{Results and Discussion}

Growing season (Apr.-Sep.) precipitation was similar during the first 3 years of the study and averaged $86 \%$ of the longterm mean (Fig. 1). During 2001, growing season precipitation was $130 \%$ of the long-term mean. Typical of wet meadow sites, the soils at our study area remained moist throughout each growing season and plant growth appeared comparable each year. Herbage standing crop at the time of the initial grazing period in May was $1,310 \mathrm{~kg} \mathrm{ha}^{-1}$ in $1998,1,580 \mathrm{~kg} \mathrm{ha}^{-1}$ in $1999,1,890 \mathrm{~kg} \mathrm{ha}^{-1}$ in 2000 , and $1,520 \mathrm{~kg}$ $\mathrm{ha}^{-1}$ in 2001. Differences in spring temperatures and accumulated growing-degree days likely contributed to variability in initial standing crop. Average herbage height at the time of the initial grazing period was $25 \mathrm{~cm}$.

\section{Standing Crop Disappearance and \\ Height}

Averaged across all grazing periods, pre-grazing herbage standing crop was $2,420 \mathrm{~kg} \mathrm{ha}^{-1}$ in 1998 and $2,810 \mathrm{~kg} \mathrm{ha}^{-1}$ in 1999. Pre-grazing height of the herbage averaged $42 \mathrm{~cm}$ in 1998 and $45 \mathrm{~cm}$ in 1999. Cumulative standing crop disappear- 
Table 1. Cumulative standing crop disappearance and cumulative height reduction for combinations of 3 stocking rates and 2 grazing frequencies on a Sandhills meadow.

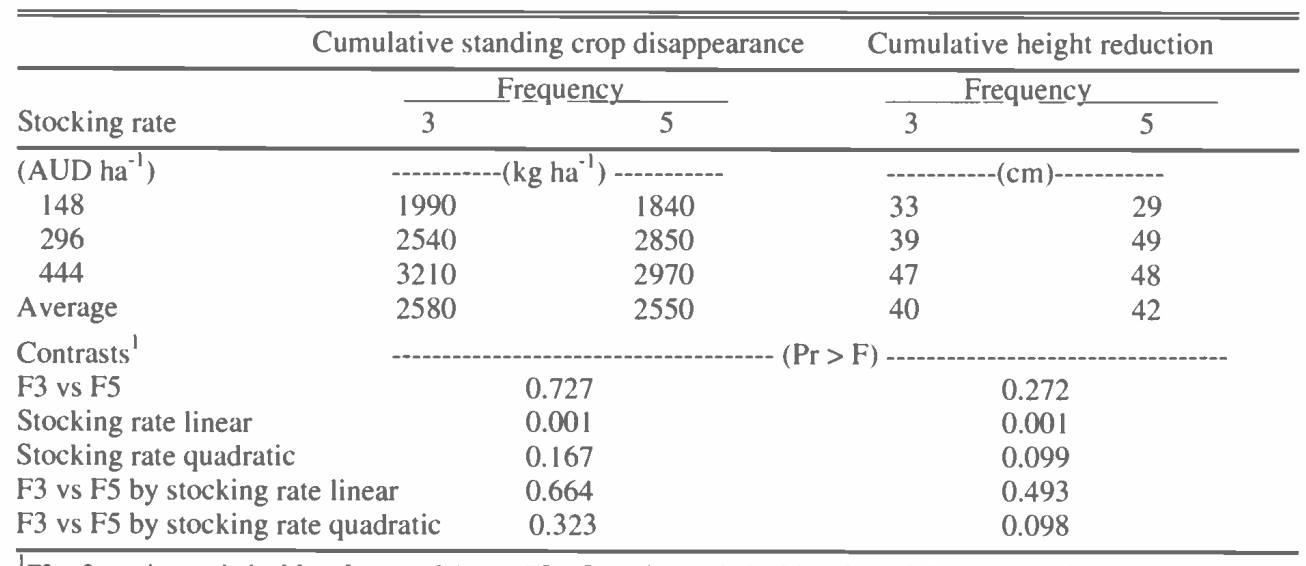

${ }^{\top} \mathrm{F} 3=3$ grazing periods (May, June, and Aug.); F5 = 5 grazing periods (May, June, July, Aug. and Sept.).

ance averaged $2,160 \mathrm{~kg} \mathrm{ha}^{-1}$ and did not differ among years. However, cumulative height reduction (sum of the differences in pre- and post-grazing height) was greater in $1998(42 \mathrm{~cm})$ than in $1999(27 \mathrm{~cm})$.

Frequency of grazing (F3 vs F5) did not affect cumulative standing crop disappearance or cumulative height reduction (Table 1). Gillen et al. (1991) reported similar results on tallgrass prairie in Oklahoma where standing crop disappearance was estimated at 45,44 , and $47 \%$ for grazing schedules with 2,3 , and 4 cycles, respectively.

Cumulative standing crop disappearance increased linearly with increasing stocking rate (Table 1). Disappearance was 1,920, 2,700 , and $3,090 \mathrm{~kg} \mathrm{ha}^{-1}$ for the 148,296 , and 444 AUD ha ${ }^{-1}$ stocking rates, respectively. Assuming that an animal unit consumes $11.8 \mathrm{~kg}$ of forage dry matter each day (SRM 1974), disappearance should have been approximately $1,760,3,490$, and $5,240 \mathrm{~kg} \mathrm{ha}^{-1}$ of forage dry matter for the 148, 296, and 444 AUD ha ${ }^{-1}$ treatments, respectively. Actual disappearance at the 148 AUD ha ${ }^{-1}$ stocking rate was higher than expected. This may have been associated with lower harvest efficiency and more waste at the low stocking rate. Herbage at this stocking rate grew more rapidly than consumption and resulted in the accumulation of mature, less palatable herbage in the pastures, as indicated by end-of-season standing crop greater than $3,200 \mathrm{~kg} \mathrm{ha}^{-1}$. Patch grazing was also observed in these pastures and appeared to be greater compared to the pastures grazed at higher stocking rates.

The lower than expected disappearance at the high stocking rate may be attributed to reduced herbage availability and reduced animal intake. Visual observations made during the second day of the 2day grazing periods noted less cattle grazing activity in the 444 AUD ha $^{-1}$ treatment compared to the lighter stocking rates. This was particularly evident during the initial grazing in May when herbage standing crop was at its lowest. Gillen et al. (1991) and Ralphs et al. (1990) reported that changes in disappearance or end-of-season standing crop were proportional to increases in stocking rate, however, average stocking rate levels in their studies were considerably less than in ours.

Grazing pressure accounted for $52 \%$ of the variation in the percentage standing crop disappearance among pastures (Fig. 2a). The average rate at which disappearance increased was about $5 \%$ per 13 AUD $\mathrm{Mg}^{-1}$ from 10 to $90 \mathrm{AUD} \mathrm{Mg}^{-1}$ and about $5 \%$ per 30 AUD $\mathrm{Mg}^{-1}$ from 90 to 150 AUD $\mathrm{Mg}^{-1}$. Similar to the relationship between standing crop disappearance and stocking rate, actual percentage standing crop disappearance at the moderate to high grazing pressure levels was less than expected, with few data points over $50 \%$. Post-grazing standing crop for grazing periods with meadow. a grazing pressure greater than 40 AUD $\mathrm{Mg}^{-1}$, averaged $1,110 \mathrm{~kg} \mathrm{ha}^{-1}$. This quantity of herbage would normally be considered adequate and should not limit intake; however, palatability factors such as a high proportion of stems and fouling from dung and urine likely reduced additional grazing of the sward. This is similar to our findings associated with cumulative standing crop disappearance data, where greater disappearance was expected under the highest stocking rate treatment.

Cumulative height reduction also increased linearly with increasing stocking rate (Table 1). Averaged over grazing frequencies, height reduction was 31,44 , and $48 \mathrm{~cm}$ for the 148, 296, and 444 AUD hastocking rates, respectively. Gillen et al. (1990) found shorter height of big bluestem tillers under heavy versus light stocking. For the 3 and 5 time grazing frequencies, pregrazing height increased from early to late grazing periods for the 148 AUD ha ${ }^{-1}$ treatments indicating herbage was growing faster than it was being consumed. For the 2 higher stocking rates, pre-grazing height declined after the second grazing period for $\mathrm{F} 3$ and after the third grazing period for F5.

Yield from the July hay harvest in the control plots averaged $6,370 \pm 250 \mathrm{~kg} \mathrm{ha}^{-1}$ in 1998 and $5,320 \pm 360 \mathrm{~kg} \mathrm{ha}^{-1}$ in 1999 . These yields were considerably higher than average cumulative standing crop disappearance from the grazed treatments $\left(2,570 \mathrm{~kg} \mathrm{ha}^{-1}\right)$. The differences likely were a result of trampling losses that occurred during each of the grazing periods and the relatively large amounts of residual plant material remaining at the conclusion of the grazing periods.

Table 2. Crude protein content (dry matter basis) of available pre- and post-grazing herbage for combinations of 3 stocking rates and 2 grazing frequencies and control pastures on a Sandhills

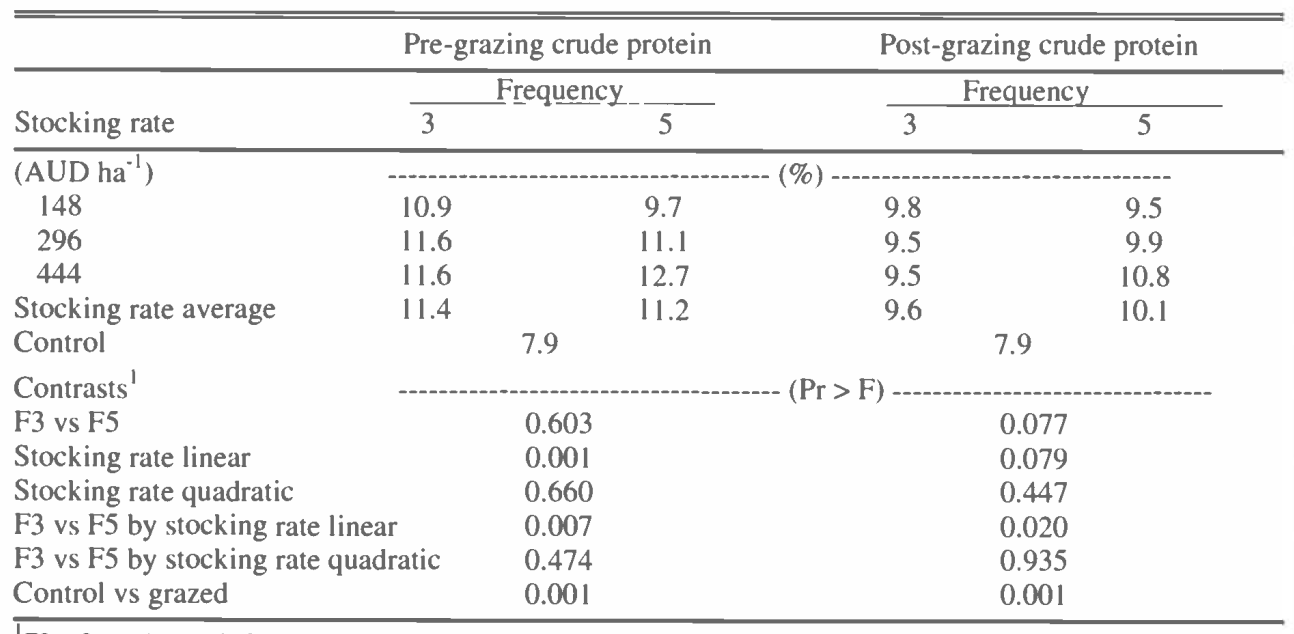

${ }^{\mathrm{I}} \mathrm{F} 3=3$ grazing periods (May, June, and Aug.); F5 = 5 grazing periods (May, June, July, Aug. and Sept.). 


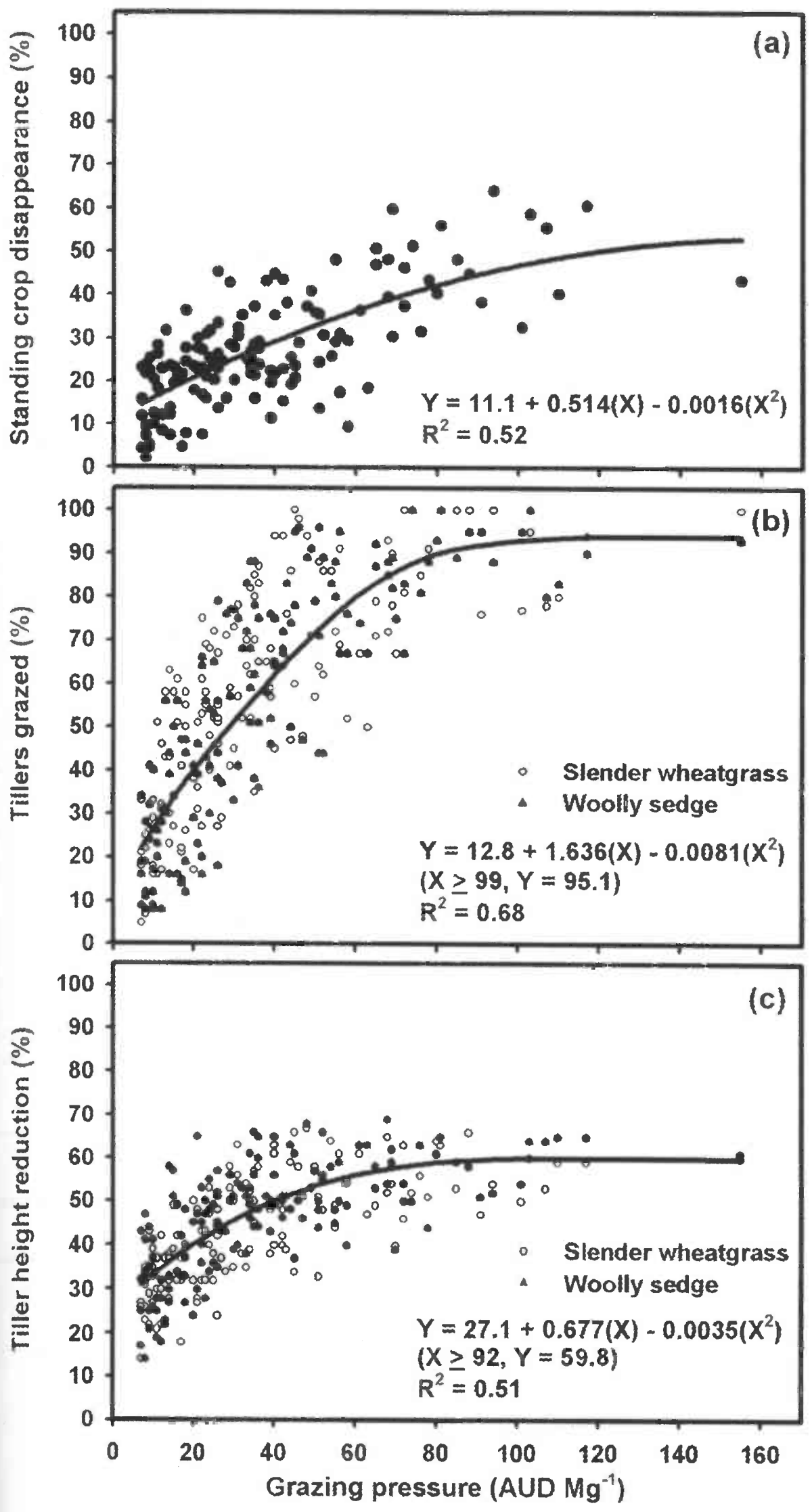

Fig. 2. Effects of grazing pressure on (a) herbage standing crop disappearance, (b) percentage of tillers grazed, and (c) percentage tiller height reduction.

\section{Crude Protein Content}

Averaged across stocking rates and grazing frequencies, crude protein $(\mathrm{CP})$ content of available pre-grazing herbage averaged $11.3 \%$ compared to $9.8 \%$ for post-grazing herbage (Table 2). Crude protein content response to stocking rate varied by grazing frequency both before and after grazing. In frequency $3(\mathrm{~F} 3)$ pastures, $\mathrm{CP}$ content before and after grazing was only slightly affected by stocking rate; whereas, $\mathrm{CP}$ of herbage before and after grazing increased in frequency 5 (F5) pastures with increasing stocking rate. The higher stocking rates appeared to result in more uniform grazing distribution and more of the herbage being maintained in a vegetative growth stage through the growing season. In F5 pastures, average length of recovery period was shorter compared to $\mathrm{F} 3$ pastures and resulted in pre-grazing herbage that was less mature than herbage in $\mathrm{F} 3$ pastures.

Average CP content of herbage from control pastures $(7.9 \%)$ was lower than that from grazed pastures because of greater maturity for plants in the control pastures (Table 2). Seasonally, CP of available herbage from control pastures was $12.1 \%$ in May and declined at each sampling date to $6.5 \%$ in September. Cool-season grasses in meadows at this location typically begin reproductive stages of growth by mid to late June. On a similar wet meadow, Horney (1999) reported CP content of July-harvested hay to be $9 \%$ and diet samples from fistulated cows contained from $16.7 \%$ CP in May to $11.6 \%$ in July.

\section{Defoliation of Key Species}

Over all treatments and grazing periods, $63.3 \%$ of slender wheatgrass and $60.5 \%$ of the woolly sedge tillers were grazed. Percentage of tillers grazed increased with stocking rate for both species (Table 3 ). For both species, percentage of tillers grazed was greater under F3 compared to F5 . Averaged over stocking rates, percentage of slender wheatgrass tillers grazed in F3 was $70.6 \%$ compared to $56.1 \%$ in F5. Percentage of woolly sedge tillers grazed in F3 was $71.3 \%$ compared to $49.8 \%$ in F5.

The higher percentage of tillers grazed in the F3 treatments likely was a result of higher grazing pressures (Table 3 and Fig. 3 ). Similarly, the percentage of tillers grazed for slender wheatgrass and woolly sedge was highest during the first grazing period in May $(69 \%)$ when grazing pressure was also highest. Beginning the grazing season with fewer animals and adding animals as the season progressed would 


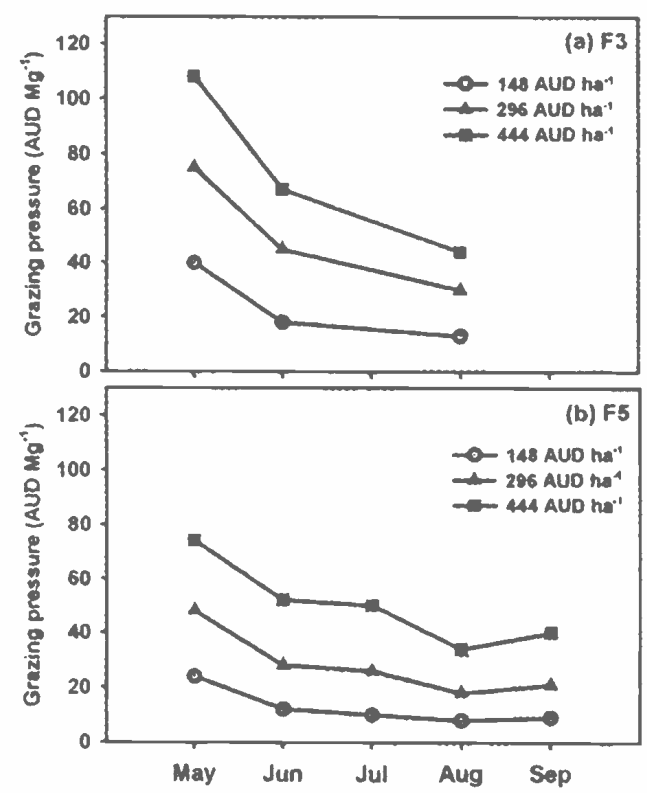

Fig. 3. A verage grazing pressure at 3 stocking rates for pastures grazed (a) 3 times (F3) or (b) 5 times (F5), 1998 and 1999.

reduce the difference in grazing pressure between early and late season.

Percentage of slender wheatgrass and woolly sedge tillers grazed increased rapidly from about $25 \%$ at $8 \mathrm{AUD} \mathrm{Mg}^{-1}$ to $90 \%$ at $80 \mathrm{AUD} \mathrm{Mg}^{-1}$ (Fig. 2b), with no difference between the 2 species. Grazing pressure accounted for $68 \%$ of the variation in percentage of tillers grazed. Cullan et al. (1999) found grazing pressure accounted for $69 \%$ of the variation in percentage of prairie sandreed [Calamovilfa longifolia (Hook.) Scribn.] tillers grazed on upland Sandhills range.

\section{Percentage Height Reduction of Grazed Tillers}

Mean percentage height reduction of grazed tillers of both slender wheatgrass and woolly sedge increased with increasing stocking rate (Table 4). Averaged over both grazing frequencies, percentage height reduction of slender wheatgrass was 39,48 , and $52 \%$ for the 148,296 , and 444 AUD ha ${ }^{-1}$ stocking rates, respectively. Percentage height reduction of woolly sedge was $34 \%, 50 \%$, and $53 \%$ for 148 , 296, and 444 AUD ha ${ }^{-1}$ stocking rates, respectively. Grazing frequency (F3 vs F5) did not affect percentage height reduction. In pastures grazed 2, 3, or 4 times, Gillen et al. (1990) found no difference in percentage height reduction of big bluestem or little bluestem [Schizachyrium scoparium (Michx.) Nash]. Grazing pressure accounted for $51 \%$ of the variation in percentage height reduction of grazed slender wheatgrass and woolly sedge tillers (Fig. 2c). Percentage height reduc- tion increased from about $32 \%$ at 8 AUD $\mathrm{Mg}^{-1}$ to $59 \%$ at $90 \mathrm{AUD} \mathrm{Mg}^{-1}$. Consistent with standing crop disappearance, percentage height reduction of the 2 species did not increase at moderate to high grazing pressures. There was no difference between the 2 species in percentage height reduction.

\section{End-of-Season Herbage Standing Crop and Total Production}

End-of-season herbage standing crop averaged $2,160 \mathrm{~kg} \mathrm{ha}^{-1}$ in grazed treatments and was not affected by year or grazing frequency (Table 5). Increasing stocking rate resulted in a linear decline in end-of-season herbage standing crop. This corresponds with our results that show greater standing crop disappearance at higher stocking rates (Table 1). Averaged across grazing frequencies, end-of-season standing crop was $3,350,1,760$, and 1,350 $\mathrm{kg} \mathrm{ha}^{-1}$ for the 148,296, and 444 AUD ha ${ }^{-1}$ stocking rates, respectively. Similarly, Ralphs et al. (1990) and Gillen et al. (1998) found end-of-season standing crop

Table 3. Average percentage of slender wheat grass and woolly sedge tillers grazed for combinations of 3 stocking rates and 2 grazing frequencies.

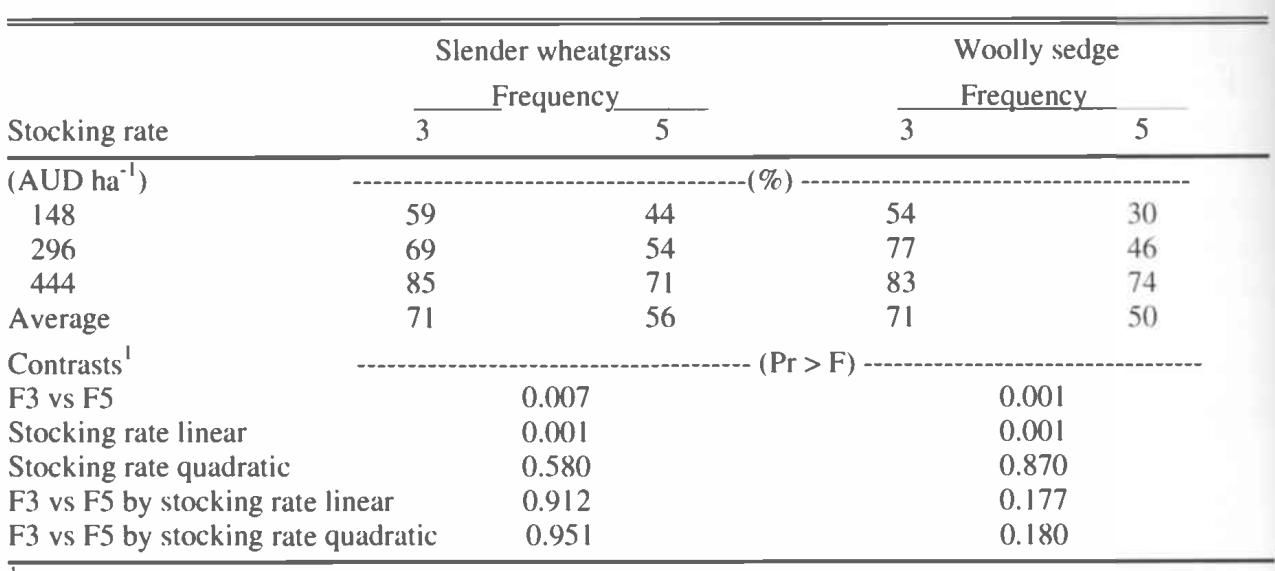

${ }^{1} \mathrm{~F} 3=3$ grazing periods (May, June, and Aug.); F5 = 5 grazing periods (May, June, July, Aug. and Sept.)

Table 4. Mean percentage height reduction of slender wheatgrass and woolly sedge for combinations of 3 stocking rates and 2 frequencies of grazing on a Sandhills meadow.

\begin{tabular}{|c|c|c|c|c|}
\hline \multirow[b]{2}{*}{ Stocking rate } & \multicolumn{2}{|c|}{$\begin{array}{c}\text { Slender wheatgrass } \\
\text { Frequency }\end{array}$} & \multicolumn{2}{|c|}{$\begin{array}{l}\text { Woolly sedge } \\
\text { Frequency }\end{array}$} \\
\hline & 3 & 5 & 3 & 5 \\
\hline \multicolumn{5}{|l|}{$\left(\right.$ AUD ha $\left.^{-1}\right)$} \\
\hline 148 & 43 & 35 & 36 & 33 \\
\hline 296 & 54 & 41 & 56 & 43 \\
\hline 444 & 54 & 51 & 54 & 52 \\
\hline Average & 50 & 42 & 49 & 43 \\
\hline \multicolumn{5}{|l|}{ Contrasts $^{\prime}$} \\
\hline F3 vs F5 & & & & \\
\hline Stocking rate linear & & & & \\
\hline Stocking rate quadratic & & & & \\
\hline F3 vs F5 by stocking rate linear & & & & \\
\hline F3 vs F5 by stocking rate quadrat & atic & & & \\
\hline
\end{tabular}

${ }^{\mathrm{F}} \mathrm{F} 3=3$ grazing periods (May, June, and Aug.); F5 = 5 grazing periods (May, June, July, Aug. and Sept.) 
Table 5. End-of-season herbage standing crop and total production for combinations of $\mathbf{3}$ stocking rates and 2 grazing frequencies on a Sandhills meadow.

\begin{tabular}{|c|c|c|c|c|}
\hline \multirow[b]{2}{*}{ Stocking rate } & \multicolumn{2}{|c|}{$\begin{array}{c}\text { End-of-season standing crop } \\
\text { Frequency }\end{array}$} & \multicolumn{2}{|c|}{$\begin{array}{l}\text { Total production } \\
\text { Frequency }\end{array}$} \\
\hline & 3 & 5 & 3 & 5 \\
\hline \multicolumn{5}{|l|}{$\left(\right.$ AUD ha $\left.^{-1}\right)$} \\
\hline 148 & 3460 & 3250 & 8860 & 8340 \\
\hline 296 & 1950 & 1570 & 7120 & 6700 \\
\hline 444 & 1700 & 990 & 7260 & 5850 \\
\hline Stocking rate average & 2370 & 1940 & 7750 & 6960 \\
\hline July-hay ${ }^{2}$ & \multicolumn{2}{|c|}{2200} & \multicolumn{2}{|c|}{8040} \\
\hline Control & \multicolumn{2}{|c|}{5650} & \multicolumn{2}{|c|}{5650} \\
\hline \multicolumn{5}{|l|}{ Contrasts $^{3}$} \\
\hline F3 vs F5 & \multicolumn{2}{|c|}{0.124} & \multicolumn{2}{|c|}{0.148} \\
\hline Stocking rate linear & \multicolumn{2}{|c|}{0.001} & \multicolumn{2}{|c|}{0.006} \\
\hline Stocking rate quadratic & \multicolumn{2}{|c|}{0.160} & \multicolumn{2}{|c|}{0.243} \\
\hline \multicolumn{2}{|l|}{ F3 vs F5 by stocking rate linear } & 0.477 & \multicolumn{2}{|c|}{0.492} \\
\hline \multicolumn{2}{|c|}{ F3 vs F5 by stocking rate quadratic } & 0.985 & \multicolumn{2}{|c|}{0.619} \\
\hline \multicolumn{2}{|c|}{ Control vs grazed } & 0.001 & \multicolumn{2}{|c|}{0.024} \\
\hline \multicolumn{2}{|l|}{ July-hay vs grazed treatments } & 0.881 & \multicolumn{2}{|c|}{0.327} \\
\hline \multicolumn{2}{|l|}{ July-hay vs control } & 0.001 & \multicolumn{2}{|c|}{0.017} \\
\hline
\end{tabular}

For grazed treatments, total production is the sum of the initial pre-grazing standing crop, difference in standing crop between pre-grazing of each subsequent grazing period and post-grazing of each previous grazing period, and end-ofseason standing crop. For the July-hay treatment, it is the sum ofthe July hay yield and end-of-season standing crop. One-half of control pastures were hayed in mid-July of each year.

${ }^{3} \mathrm{~F} 3=3$ grazing periods (May, June, and Aug.); F5 = 5 grazing periods (May, June, July, Aug. and Sept.)

in a more open canopy after defoliation and favored growth of tillers that emerged later in the growing season, contributing to greater total production. However, at higher stocking rates, this effect was less pronounced.

\section{Plant Species or Group Frequency of Occurrence}

Frequency of occurrence averaged $80 \%$ for slender wheatgrass, $70 \%$ for woolly sedge, $38 \%$ for Kentucky bluegrass, $58 \%$ for other cool-season grasses, $7 \%$ for warm-season grasses, $39 \%$ for other sedges, $58 \%$ for rushes, $59 \%$ for legumes, and $5 \%$ for forbs. Frequency of occurrence of these species or groups was not

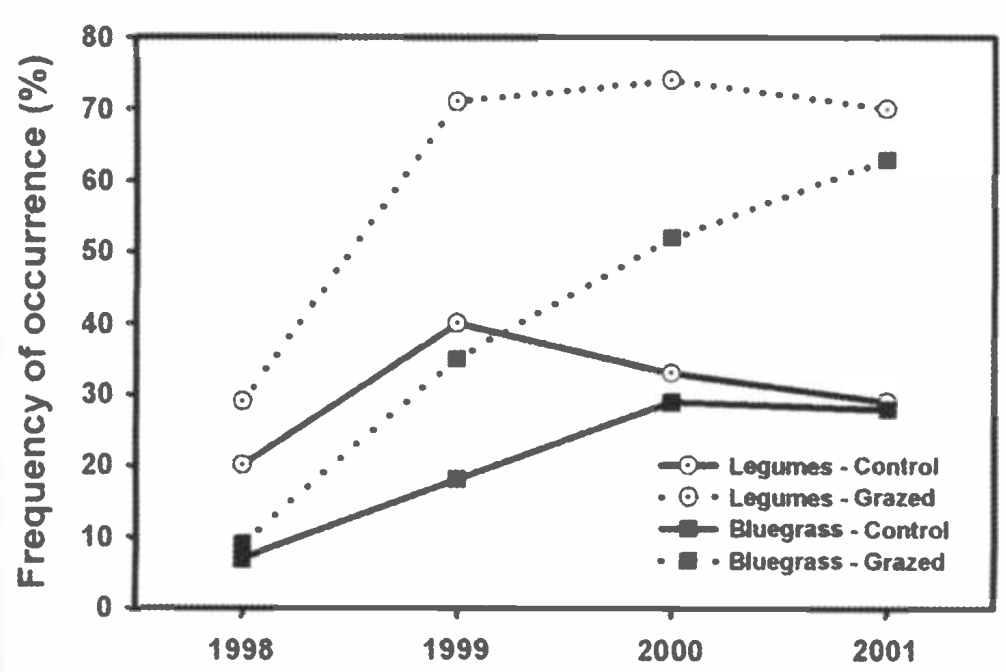

Fig 4. Frequency of occurrence of legumes and Kentucky bluegrass in grazed and control wet meadow pastures, 1998-2001.

affected by stocking rate or grazing frequency during any year of the study.

For grazed pastures compared to the legumes and Kentucky bluegrass was similar in 1998 (Fig. 4). However, from 1999 through 2001 , frequency of occurrence of legumes and Kentucky bluegrass was higher in the grazed pastures compared to the control. White, red, and alsike clover constituted the majority of the legume group and are naturalized in many Sandhills wet meadows. Grazing opened the dense grass and sedge canopy and was most likely a primary factor in developing conditions favorable to legumes. White clover is a particularly opportunistic control, frequency of occurrence of legume that has a prostrate growth habit and thrives in moist habitats that are closely mowed or grazed (Pederson 1995). Kentucky bluegrass is a persistent, lowgrowing, sod-forming species that invades heavily grazed tallgrass pastures in eastern Nebraska (Samson and Moser 1982, Waller and Schmidt 1983).

The lack of treatment effects, particularly stocking rate, on frequency of occurrence of slender wheatgrass and woolly sedge was not expected. However, the relatively low use of the 2 species and associated vegetation at the 2 higher stocking rates, or high grazing pressures, largely explains the absence of species composition change. The abundance of soil moisture in these meadow sites mitigates the effects of heavier defoliation. In an Oregon riparian meadow dominated by redtop, Clary (1995) found little change in botanical composition following 3 years of clipping treatments. However, in a mountain meadow site dominated by sedges, heavy defoliation treatments reduced annual production of sedges and increased the proportion of forbs. Bartolome (1984) suggested that most changes in wet meadow species composition occur from grazing-induced changes in meadow hydrology and lowering of the water table rather than from defoliation or compaction.

\section{Summary}

This study examined stocking rate and grazing frequency effects on standing crop and herbage height disappearance, herbage crude protein content, defoliation of key species, end-of season standing crop, and total production in a wet meadow. Stocking rate affected more response variables than grazing frequency. Standing crop disappearance was lower than projected animal intake at 444 AUD ha $^{-1}$ indicating that intake was likely depressed. This also was supported by our examination of the relationship between grazing pressure and tiller defoliation characteristics; where there was a minimal increase in the percentage of tillers grazed and percentage tiller height reduction at a grazing pressure above about 70 AUD $\mathrm{Mg}^{-1}$. During the early part of the grazing season, grazing pressure at $444 \mathrm{AUD} \mathrm{ha}^{-1}$ was near or above 70 AUD $\mathrm{Mg}^{-1}$. At our site, herbage productivity would support a stocking rate of 296 AUD ha $^{-1}$ with animal intake needs likely being met throughout the growing season.

Increasing frequency of grazing on Sandhills meadows from 3 to 5 times per 
growing season was not advantageous in terms of herbage yield, forage utilization, or species composition. Increasing frequency of grazing needs to be evaluated closely because of management and infrastructure costs associated with more frequent grazing periods.

Although we did not observe a decline in frequency of occurrence of slender wheatgrass or woolly sedge in grazed wet meadow pastures, increases were found for less productive species such as Kentucky bluegrass and white clover. Future studies are needed to determine animal productivity from wet meadows as well as long-term effects of annual grazing on meadow productivity. Additionally, opportunities exist for studies that evaluate seasonal grazing effects or strategies that combine grazing and haying.

\section{Literature Cited}

Adams, D.C., RT. Clark, S.A. Coady, J.B. Lamb, and M.K. Neilson. 1994. Extended grazing systems for improving economic returns from Nebraska Sandhills cow/calf operations. J. Range Manage. 47:258-263.

Bartolome, J.W. 1984. Impacts of grazing intensity and grazing systems on vegetation composition and production, p. 917-925. In: Developing Strategies for Rangeland Management. Westview Press, Boulder, Colo.

Clary, W.P. 1995. Vegetation and soil responses to grazing simulation on riparian meadows. J. Range Manage. 48:18-25.
Coady, S.A. and RT. Clark. 1993. Ranch management practices in the Sandhills of Nebraska: managing production. Agr. Res. Div., Inst. Agr. and Natur. Resour., Univ. Nebr.-Lincoln, Res. Bull. RB-318.

Cullan, A.P., P.E. Reece, and W.H. Schacht. 1999. Early summer grazing effects on defoliation and tiller demography of prairie sandreed. J. Range Manage. 52:447-453.

Ehlers, P., G. Viehmeyer, R Ramig, and E.M. Brouse. 1952. Fertilization and improvement of native subirrigated meadow in Nebraska. Univ. of Nebr. Agr. Exp. Sta. Circ. 92. Lincoln, Nebr.

Gillen, R.L., F.T. McCollum, and J.E. Brummer. 1990. Tiller defoliation patterns under short duration grazing in tallgrass prairie. J. Range Manage. 43:95-99.

Gillen, R.L., F.T. McCollum III, K.W. Tate, and M.E. Hodges. 1998. Tallgrass prairie response to grazing system and stocking rate. J. Range Manage. 51:139-146.

Gillen, R.L., F.T. McCollum, M.E. Hodges, J.E. Brummer, and K.W. Tate. 1991. Plant community responses to short duration grazing in tall grass prairie. J. Range Manage. 44: 124-128.

Horney, M.D. 1999. Spring grazing: A management alternative for Sandhills wet meadows. Ph.D. Diss., Univ. Nebr.-Lincoln, Lincoln, Nebr.

Horney, M., D. Adams, W. Schacht, S. Waller, and T. Klopfenstein. 1996. Grazing an alternative to haying subirrigated meadows in the Nebraska Sandhills. p. 6-7. In: 1996 Beef Cattle Report. MP 66-A. Univ. Nebr.-Lincoln, Lincoln, Nebr.

Karl, M.G. and R.A. Nicholson. 1987. Evaluation of the forage-disk method in mixed-grass rangelands of Kansas. J. Range Manage. 40:467-471.
Pederson, G.A. 1995. White clovers and other perennial clovers, p. 227-236. In: R.F. Barnes, D.A. Miller, and C.J. Nelson (ed.) Forages, Vol. I: An Introduction to Grassland Agriculture. Iowa State Univ. Press. Ames, lowa.

Poole, R.J. 1914. A study of the vegetation of the Sandhills of Nebraska. Minn. Bot. Studies 4:187-312.

Ralphs, M.R., M.M. Kothmann, and C.A. Taylor. 1990. Vegetation response to increased stocking rates in short-duration grazing. J. Range Manage. 43: 104-108.

Rundquist, D.C. 1983. Wetland inventories of Nebraska's Sandhills. Nebr. Remote Sensing Center and Conser. and Survey Div. Univ. Nebr.-Lincoln. Resource Rep. No.5; Lincoln, Nebr.

Samson, J.F. and L.E. Moser. 1982. Sodseeding perennial grasses into eastern Nebraska pastures. Agron. J. 74:1055-1060.

SAS. 1995. User's Guide: Statistics. 1995 Edition. SAS Institute, Inc., Cary, N.C.

Sharrow, S. H. 1984. A simple disc meter for measurement of pasture height and forage bulk. J. Range Manage. 37:94-95.

Society for Range Management. 1974. A Glossary for Terms Used in Range Management. $2^{\text {nd }}$ ed. Society for Range Management. Denver, Colo.

USDA-Soil Conservation Service. 1981. Nebraska technical guide: Nebraska range sites descriptions and guide for determining range condition and suggested initial stocking rates. Section II-D-I. USDA-SCS.

Volesky, J.D., D.C. Adams, and R.T. Clark. 2002. Windrow grazing and baled-hay feeding strategies for wintering calves. J. Range Manage. 55:23-32.

Waller, S.S. and D.K. Schmidt. 1983. Improvement of eastern Nebraska tallgrass range using atrazine or glyphosate. J. Range Manage. 36:87-90. 